\title{
Supersterren en superinkomens
}

Citation for published version (APA):

Borghans, L., \& Groot, L. (2003). Supersterren en superinkomens. Sociologische Gids, 50(1), 71-90.

Document status and date:

Published: 01/01/2003

Document Version:

Publisher's PDF, also known as Version of record

\section{Please check the document version of this publication:}

- A submitted manuscript is the version of the article upon submission and before peer-review. There can be important differences between the submitted version and the official published version of record.

People interested in the research are advised to contact the author for the final version of the publication, or visit the DOI to the publisher's website.

- The final author version and the galley proof are versions of the publication after peer review.

- The final published version features the final layout of the paper including the volume, issue and page numbers.

Link to publication

\footnotetext{
General rights rights.

- You may freely distribute the URL identifying the publication in the public portal. please follow below link for the End User Agreement:

www.umlib.nl/taverne-license

Take down policy

If you believe that this document breaches copyright please contact us at:

repository@maastrichtuniversity.nl

providing details and we will investigate your claim.
}

Copyright and moral rights for the publications made accessible in the public portal are retained by the authors and/or other copyright owners and it is a condition of accessing publications that users recognise and abide by the legal requirements associated with these

- Users may download and print one copy of any publication from the public portal for the purpose of private study or research.

- You may not further distribute the material or use it for any profit-making activity or commercial gain

If the publication is distributed under the terms of Article $25 \mathrm{fa}$ of the Dutch Copyright Act, indicated by the "Taverne" license above, 


\section{Supersterren en superinkomens}

1. Inleiding

In dit artikel proberen we inzichtelijk te maken welke mechanismen aan supersterren en supersterinkomens ten grondslag liggen. De opkomst van supersterren als Madonna, Ronaldo, Ophrah Winfrey maar ook Bill Gates is geen toevalligheid, maar nauw verbonden met de steeds grotere rol van massamedia en reproductietechnologieën in ons dagelijks leven. Supersterren maken gebruik van de massamedia om het publiek te bereiken en van een reproductietechnologie om hun klanten te bedienen. Dit duidt erop dat het niet zozeer sociaal-culturele veranderingen zijn, zoals ontkerkelijking, ${ }^{\mathrm{I}}$ meer vrije tijd of veranderingen in de consumptiecultuur, die ervoor zorgen dat supersterren zo op de voorgrond treden. De opkomst van de superster is, zo betogen wij, met name het gevolg van de beschikbaarheid van goedkope reproductietechnologie. Zonder reproductie geen superster.

De steeds gemakkelijkere reproduceerbaarheid van de producten van supersterren gaat gepaard met allerlei interessante randverschijnselen, zoals een verhevigde strijd om de auteursrechterlijke bescherming van intellectueel eigendom, de rol van reclame en, in het verlengde daarvan, de verschuiving van een markt- naar een marketingeconomie. Deze zaken komen slechts zijdelings aan de orde. In plaats daarvan richten we onze aandacht in het tweede deel van deze bijdrage op de vraag of de uitzonderlijk hoge inkomens die supersterren toucheren, wel verdedigbaar zijn. Op grond van een vergelijking tussen een markt met normale productie en een markt met mediaproductie, laten we zien dat als supersterinkomens beperkt blijven tot wat iemand bijdraagt aan de maatschappelijke welvaart, massamedia het weliswaar mogelijk maken voor de meest getalenteerde supersterren om een steeds grotere markt te bedienen, maar dat toenemende competitie om de bijzondere positie van superster het loon in balans zal houden. De uitzonderlijk hoge en steeds groeiende inkomens van supersterren kunnen dan ook alleen verklaard worden doordat supersterren zich een veel groter deel van de maatschappelijke koek toe-eigenen dan zijzelf bijdragen. Veranderingen in de eigendomsrechten zullen nodig zijn om deze balans weer 
te herstellen. Bijvoorbeeld, door het gratis kopiëren van muziek via internet lijkt het supersterinkomen van popmusici weer op het niveau te komen dat het zou moeten zijn, niet alleen vanuit welvaarttheoretisch oogpunt maar ook op grond van wat hun bijdrage is aan de maatschappelijke productie. We besluiten deze bijdrage met een korte recapitulatie.

Sinds de Tweede Wereldoorlog treedt het fenomeen van supersterren met extreem hoge inkomens steeds sterker op de voorgrond, gelijke pas houdend met de steeds grotere rol van massamedia in het dagelijks leven. Deze ontwikkeling is in gang gezet met de opkomst van radio en televisie en heeft nieuwe impulsen gekregen door de introductie van satelliet-tv en internet en door digitale technieken zoals cd en dvd. De beste acteurs, regisseurs, violisten, popmusici, sporters, schrijvers, softwareproducenten enzovoort, weten jaarcontracten te bedingen waarbij fabuleuze bedragen worden neergeteld zodat de gevleugelde uitspraak 'The sky is the limit' hier werkelijkheid lijkt te worden. Ieder jaar worden nieuwe records gebroken. Blijkens de Forbes' list 2002 verdienen George Lucas, Oprah Winfrey en Steven Spielberg respectievelijk 200, I50 en 104 miljoen dollar op jaarbasis. Met het op de voorgrond treden van het supersterfenomeen lijkt een nieuwe tak van de astronomie haar intrede te kunnen doen, want vele verschijnselen waarmee we vanuit dit domein bekend zijn vinden hier hun parallel. Zoals afstanden tussen hemellichamen ons bevattingsvermogen te boven gaan, zo behoren inkomens met een factor rooo van wat modaal verdient tot de mogelijkheden. Sommige sterren blijven langere tijd schitteren, anderen is slechts een komeetachtige carrière beschoren. Gewone stervelingen dichten hen zowel ongenaakbaarheid als een bovennatuurlijke superioriteit toe. Zoals met het heelal onttrekt ook nu het grootste deel zich aan het oog. We zien alleen de successen, maar doorgaans niet degenen voor wie het succes niet is weggelegd of de tragiek van degenen voor wie het succes net niet binnen handbereik komt. Zij hebben er alles voor gedaan, maar blijkbaar toch niet genoeg. Bij een extreem zware competitie tussen een zeer groot aantal deelnemers is het zelfs voor de zéér getalenteerden een loterij of zij daadwerkelijk tot de besten zullen behoren, want het toevalselement geeft bij zeer kleine verschillen de doorslag.

De vraag die in dit artikel aan de orde komt is niet alleen hoe supersterinkomens kunnen worden verklaard, maar ook of de steeds rijker wordende supersterren deze inkomens ook werkelijk verdienen. Is het zo dat sportmensen, artiesten en programmeurs dankzij de massamedia steeds beter hun uitzonderlijk talent te gelde kunnen maken, of hebben de massamedia nieuwe bronnen van welvaart geopend die supersterren zich toe-eigenen? We bekijken deze vraag vanuit het uitgangspunt dat iedereen recht heeft op zijn 'marginale bijdrage' aan de maatschappelijke welvaart. Volgens de binnen de economische wetenschap dominante neoklassieke theorie, zullen bij een goed functionerende markt alle arbeidsinkomens gelijk zijn aan de marginale productiviteit die door vraag en aanbod wordt bepaald: een 
werkgever neemt extra werknemers aan zolang de extra opbrengsten van uitbreiding van de productie hoger zijn dan de toename in de loonkosten. De marginale bijdrage aan de maatschappelijke welvaart die iemand levert kan men zich - zo betogen wij- het beste voorstellen door een vergelijking te maken met de denkbeeldige situatie dat de betreffende persoon nooit geboren zou zijn. Dit klinkt in dit stadium tamelijk abstract, maar het zal in sectie 3 aan de hand van een voorbeeld aanschouwelijk worden gemaakt.

Voor supersterren geldt dat wat zij leveren vaak van uitzonderlijk hoge kwaliteit is, maar er tevens vele anderen klaar staan om de rol van topartiest of topatleet over te nemen. Massamedia leiden dus tot meer mogelijkheden om talent ten toon te spreiden, maar ook tot meer competitie. De praktijk leert dat ondanks het feit dat de markten waarop supersterren opereren vaak het toonbeeld zijn van vrije concurrentie, de neerwaartse druk op de beloningen voor supersterren niet zodanig is dat deze tot normale proporties worden teruggebracht. Dit betekent ofwel dat de talenten van supersterren zo uitzonderlijk zijn in vergelijking met hun directe rivalen dat deze superinkomens op hun plaats zijn, óf dat het economisch systeem niet meer in staat is om de neoklassieke balans tussen extra beloning voor talent en beloningsdruk door competitie in evenwicht te houden. Hoewel het goed voor te stellen is dat de waarde van een topvoetballer of topartiest zeer groot is - talloos vele miljoenen mensen genieten immers van hun uitzonderlijke gave - betogen wij in deze bijdrage dat dit evenwicht inderdaad zoek is. Door te analyseren welke inkomensdynamiek men zou mogen verwachten als een gewone markt verandert in een mediamarkt, laten we zien dat de feitelijke ontwikkelingen met betrekking tot supersterren erop wijzen dat enkele topartiesten zich waarde toe-eigenen die eigenlijk in de activiteit besloten ligt en in die zin aan de maatschappij als geheel toekomt. Wat plaatsvindt is een zekere exploitatie van cultureel erfgoed.

Door de toenemende invloed van de massamedia en steeds betere reproductietechnieken, wordt de commerciële waarde van een activiteit meer en meer gekoppeld aan de prestaties die de enkele toppers leveren. Het is niet verwonderlijk dat in het gevecht om de enorme inkomsten die hiermee gemoeid zijn, ook de belangstelling voor auteursrechten, de juridische uitdrukkingsvorm van het intellectueel eigendom, sterk is toegenomen. Meer en meer rechtszaken worden gevoerd om de auteursrechten te beschermen van producten die gemakkelijk via digitale technieken te verspreiden zijn of anderszins kunnen worden gekopieerd. Net zoals in de negentiende eeuw de opkomst van de industrie leidde tot een onevenwichtige inkomensverdeling die gepaard ging met een opvallend intensieve juridische eigendomsstrijd, ${ }^{2}$ zo zal ook het toenemend belang van de massamedia en de daarmee verbonden commerciële belangen tot eigendomsconflicten blijven leiden. 
2. Verklaringen van supersterinkomens

De superster bij Adam Smith

In de inleiding is misschien de indruk gewekt dat het supersterfenomeen een tamelijk recent verschijnsel is. Echter, reeds bij Adam Smith (1776) kunnen we dit fenomeen terugvinden, hoewel het niet als zodanig wordt genoemd:

Er bestaan enkele aangename en mooie talenten, waarvan het bezit aanleiding geeft tot een zekere bewondering, maar waarvoor de uitoefening vanuit winstbejag, te recht of ten onrechte, gezien wordt als een soort openbare prostitutie. De financiële compensatie van degenen die deze talenten op deze wijze uitoefenen moet daarom voldoende zijn om niet alleen te compenseren voor de tijd, arbeid en onkosten voor het verwerven van dit talent, maar tevens voor de schande die het gevolg zal zijn van het uitoefenen van dit vak voor levensonderhoud. De enorme beloningen van muzikanten, operazangers, operadansers, enz. zijn op deze twee principes gebaseerd: de bijzonderheid en schoonheid van de talenten en de schande om ze op deze manier te aan te wenden. (Smith I982: 209) ${ }^{3}$

Zoals de prostitué haar lichaam tot productiemiddel transformeert en deze als waar te koop aanbiedt, zo wendt op analoge wijze de superster een andere eigenschap, talent of vaardigheid voor commerciële doeleinden aan. In de tijd van Smith werden supersterren die uit hun talent munt wilden slaan, blijkbaar eerder verguisd dan, zoals nu, aanbeden. Voor Smith hangen de hoge beloning en de verguizing dus samen:

Op het eerste gezicht lijkt het absurd dat we hun persoon minachten en we tegelijkertijd hun talenten belonen met de grootste vrijgevigheid. Als we het ene doen, moeten we echter noodzakelijk ook het ander doen. Als de publieke mening of vooroordelen met betrekking tot deze beroepen ooit wijzigen, dan zal hun financiële compensatie snel afnemen. Meer mensen zouden zich voor deze beroepen aanmelden, waardoor concurrentie snel de prijs van arbeid zal drukken. Dergelijke talenten, hoewel alles behalve gemeengoed, zijn bij lange na niet zo uitzonderlijk als vaak wordt gedacht. Veel mensen beschikken er over in grote perfectie, maar vinden het beneden hun waardigheid om ze te gebruiken, en nog veel meer mensen zouden ze kunnen verwerven als ze er iets eerbaars mee zouden kunnen doen. (ibid.: 209) ${ }^{4}$ )

Er zit een zekere logica in deze redenering (de hoge beloning is een soort compensatie voor vuil werk), maar in het huidige tijdperk waarin het commercialiseren van talent niet als prostitutie wordt gezien doet deze verklaring niet langer opgeld. 
Belangrijker is dat Smith in dit opzicht een onvoorwaardelijk vertrouwen in de werking van de markt uitspreekt, waarin hij geen gelijk heeft gekregen. Als de activiteit van een superster lovens- en benijdenswaardig in plaats van afkeurenswaardig zou zijn, dan zou volgens Smith de onderlinge wedijver snel een einde maken aan hoge beloningen. Smith veronderstelt dat de onderlinge wedijver en de mogelijkheid van substitutie van de ene performer voor de andere in principe de beloningsverschillen in het gareel zullen houden. Dat zich toch nog grote beloningsverschillen voordoen, wijt hij niet aan het gebrekkig functioneren van de markt, maar aan het feit dat slechts een enkeling bereid is zijn talent te prostitueren. Maar waarom zou ertussen die enkelingen niet reeds (prijs)concurrentie ontstaan? Het supersterfenomeen heeft zich in embryonale vorm in Smith's tijd dus wel voorgedaan, maar hij is in zijn analyse aan het supersterdom voorbij gegaan. Vele populaire sporten en andere takken van de amusementsindustrie laten momenteel namelijk zien dat een grotere populariteit en een grotere onderlinge wedijver alleen maar versterkend werken op de hoogte van het inkomen van de superster. Blijkbaar wordt door Smith een factor over het hoofd gezien. We zullen ons nu richten op hedendaagse auteurs.

\section{Hedendaagse verklaringen van supersterinkomens}

In twee artikelen in de American Economic Review heeft Rosen een model ontwikkeld dat een verklaring wil geven voor het fenomeen van supersterinkomens. Binnen dit model kunnen drie verschillende oorzaken worden aangewezen. Ten eerste imperfecte substitutie tussen kwaliteit. Rosen geeft als voorbeelden dat een serie optredens van een middelmatige zanger niet kan opwegen tegen één topoptreden, dat mensen meer dan Io\% extra willen betalen voor een chirurg met een 10\% hogere score in succesvolle operaties, of dat een bedrijf bereid is een zeer hoog tarief voor een topadvocaat te betalen als met de rechtszaak een groot bedrag is gemoeid. Deze voorbeelden maken duidelijk dat in sommige beroepen meer dan evenredig voor kwaliteit wordt betaald en dat substitutie tussen verschillende kwaliteiten slechts in beperkte mate mogelijk is. Meer in het algemeen kunnen we stellen dat in tegenstelling tot de landbouw en de industrie, waar veelal sprake is van een homogeen product dat probleemloos kan worden gesommeerd, in bepaalde sectoren van de economie de gelimiteerde optelbaarheid van individuele prestaties aanleiding geeft tot meer dan 'evenredige' beloning voor uitzonderlijk talent. Ook in de sport doet dit fenomeen zich voor. Bij teamsporten kan een uitzonderlijke begaafde speler slechts in beperkte mate worden vervangen door twee minderbegaafden. Wat hier van belang is, is het onderscheid tussen homogene en heterogene goederen. Bij homogene goederen is de substitutie perfect en mogen afzonderlijke hoeveelheden bij elkaar worden opgeteld. De superster daarentegen kan bogen op een prestatie die zich niet zomaar laat optellen bij de prestaties van mindere coryfeeën. Het maakt niet zozeer kwantitatief, maar wel een groot kwalitatief verschil of men als eerste dan wel als laatste van het peloton de meet 
passeert. Binnen de contexten waarin supersterren hun prestaties realiseren, zijn het deze kleine kwantitatieve verschillen die de kwalitatieve breuk bewerkstelligen, waardoor de prestatie of het product van de beste zich absoluut onderscheidt van de rest. Bij individuele sporten gaat het niet om de som van de individuele prestaties, maar om de rangorde. Bovendien is die rangorde ten opzichte van elkaar belangrijker dan het niveau dat ieder voor zich kan bereiken.

Imperfecte substitutie tussen kwaliteit alleen kan niet verklaren waarom één of enkele individuen een groot deel van de toegevoegde waarde van een deelmarkt naar zich toe kunnen halen, wat kenmerkend is voor het supersterfenomeen. Het effect van imperfecte substitutie kan echter aanmerkelijk worden versterkt indien van een medium (audiovisuele media, boeken, software, enz.) gebruiktgemaakt kan worden, waardoor een groot deel van de markt door één en dezelfde aanbieder kan worden bediend. Bijvoorbeeld, in Brabant waren er vroeger vele 'tonpraters', die de dorpen langs trokken en het werk deden wat nu wordt gedaan door nationaal opererende cabaretiers. Door de beschikbaarheid van een medium wordt enerzijds de dienst die de superster levert van zijn eenmaligheid ontdaan en krijgt het product het karakter van een non-rivaliserend goed (de consumptie van de één gaat niet ten koste van de consumptie van de ander), anderzijds stijgen de kosten van productie (van het schrijven, uitvoeren, enz.) niet evenredig met de omvang van de markt. Kosteloze reproductie met een homogeen product geeft slechts één superster en kosteloze reproductie met een heterogeen product geeft meer supersterren, elk met een eigen segment zoals een groot deel van de culturele industrie (muziek, literatuur, film, software, enz.) laat zien. Achteraf kunnen we stellen dat bij het voorbeeld van de operazanger bij Adam Smith reeds een embryonale vorm van reproductie in combinatie met imperfecte substitutie aanwezig was.

Als derde oorzaak, naast imperfecte substitutie en goedkope of zelfs kosteloze reproductie, noemt Rosen de 'opportunity costs' van consumptie. Bij het bezoeken van een film bestaan de kosten niet alleen uit de entreeprijs, maar ook uit de tijd die men besteedt. Dit geldt nog sterker voor boeken, cd's, enz. Het belang van deze factor is dat hoe hoger deze 'tijdkosten' per eenheid consumptie (die hoger zijn naarmate iemands inkomen hoger is), des te sterker er wordt gesubstitueerd ten gunste van hogere kwaliteit 76 en men dus meer bereid is een hogere entreeprijs te betalen, een prijs die relevant is voor de superster. Hier speelt het bekende voorbeeld een rol dat voor iemand met een hoog inkomen een biefstuk goedkoper is (tijdkosten meegerekend) dan een sudderlapje.

Naast Rosen hebben recentelijk diverse economen nog een aantal mogelijke factoren naar voren gebracht. Adler (I985) probeert aannemelijk te maken dat het fenomeen van supersterren zelfs kan optreden bij afwezigheid van verschillen in talent of verschil in kwaliteit, namelijk ten gevolge van informatiekosten bij consumptie. Cruciaal is de veronderstelling dat 
consumptie tegelijk een leerproces is (bijvoorbeeld bij muziek, literatuur, enz.), waardoor de waardering of het consumptiegenot toeneemt naarmate men beschikt over een grotere achtergrondkennis of bekendheid met de kunstvorm, het genre of de artiest. Adler verklaart waarom iemand vanwege de formatie van consumptiekapitaal (de achtergrondkennis en bekendheid met het product) zich beperkt tot enkele culturele interesses en daarbinnen tot enkele artiesten. In het geval dat iedereen een andere artiest kiest, is onderlinge discussie en daarmee informatieoverdracht onmogelijk. Echter, vanuit het oogpunt van zoekkosten is het optimaal te kiezen voor de populairste artiest. In principe kan iedereen een ster worden, het is een kwestie van geluk:

Nogmaals, een ster hoeft niet over meer talent te beschikken. Sterrendom is een marktinstrument om te bezuinigen op leerkosten bij activiteiten waar geldt 'hoe meer je weet, hoe meer je geniet'. Dus sterrendom kan onafhankelijk zijn van een hiërarchie van talent. (Adler I985: 208) ${ }^{5}$

In dit model kan iedereen in principe een ster worden, het is een kwestie van geluk:

In eerste instantie kunnen alle kleuren briefjes dienen als geld en op dezelfde manier kunnen alle artiesten sterren zijn. In tweede instantie vraagt efficiëntie echter om slechts één soort geld en op dezelfde manier vraagt efficiëntie om slechts enkele artiesten met publieke waardering (...) Als een kleine meerderheid consumenten X uit zouden kiezen, dan zou $\mathrm{X}$ door het sneeuwbaleffect aanzwellen tot een ster, omdat deze meerderheid steeds verder zal groeien. (ibid.: $2 \mathrm{II})^{6}$

In feite speelt bij de verklaring van Adler imperfecte substitutie tussen verschillende kwaliteiten zoals bij Rosen geen rol. Hoewel Adler een waardevolle bijdrage levert aan de verklaring van het fenomeen van supersterren, kan men hier niet aan de kritiek ontkomen dat als iedereen ster zou kunnen worden dit tevens verondersteld dat iedereen interessant en getalenteerd genoeg is om als ster te gaan fungeren, wat niet zo is in feite. Zo is het duidelijk dat niet iedereen een even amusante cabaretier zal zijn. Adler benadrukt onvoldoende dat supersterren vaak de beste zijn in hun metier. Maar de beste zijn, gaat niet altijd samen met een supersterstatus. Daarvoor is, wat Adler terecht opmerkt, de populariteit of bekendheid van het publiek met de ster voor nodig, zoals het bij geld nodig is dat iedereen dit erkent als wettig betaalmiddel. Voor dit laatste heeft hij 'box-office appeal' nodig, wat misschien het beste vertaald kan worden met aantrekkingskracht bij het publiek, eventueel verkregen door reclame. Als er enerzijds geen formule bestaat voor het creëren van sterren, noch te voorspellen is wie de sterren van morgen zullen zijn (conform het gezegde 'there is no such thing as a 
money machine'), dan is box-office appeal een ongewisse zaak. Anderzijds is het bij reproduceerbare prestaties rationeel (vanwege de dalende kosten) het marktaandeel zo groot mogelijk te maken. Maar omdat het marktaandeel weer afhankelijk is van de box-office appeal of de naamsbekendheid van de ster bij het publiek, zien we hier een verschuiving van een markteconomie (met stuklonen) naar die van een 'marketingeconomie' (met winnaarslonen). Tekenend hiervoor is dat het advertentiebudget van een film van Spielberg het productiebudget overtreft. Het gaat er niet alleen om een goed product aan te bieden, maar ook om een markt te veroveren door het publiek aan zich te binden.

MacDonald (I988) vergelijkt supersterinkomens met een lot gewonnen in een loterij: de sterren-in-spe nemen aanvankelijk genoegen met een lager inkomen dan ze met ander werk zouden kunnen verdienen, maar ze hebben wel de mogelijkheid later heel veel te verdienen. Het supersterinkomen heeft dan deels het karakter van een compensatie voor het lagere inkomen dat men in de aanloop heeft genoten, deels het karakter van een hoofdprijs gewonnen in de loterij. Ook Adam Smith (I982: 208) heeft hier weer een geheel eigen zienswijze:

Breng je zoon als leerling naar een schoenmaker en er is weinig twijfel dat hij zal leren hoe een paar schoenen gemaakt moet worden, maar laat hem rechten studeren en je hebt hoogstens een kans van één op twintig dat hij ooit zo bekwaam wordt dat hij in staat is van deze activiteit te leven. In een volslagen eerlijke loterij, moeten zij die de prijs trekken alles verdienen wat verdiend had moeten worden door de twintig onsuccesvolle deelnemers. De juridisch adviseur die wellicht, als hij al bijna veertig is, iets begint te verdienen aan zijn beroep, zou niet alleen een vergoeding moeten krijgen voor zijn eigen langdradige en dure opleiding, maar ook voor de compensatie van de twintig anderen die er waarschijnlijk nooit iets uit zullen halen. ${ }^{7}$

Smith ziet dit soort beroepen als een soort kansspelen en zijn voornaamste bezwaar is niet de concentratie van opbrengsten bij de enkeling, maar dat het geen faire loterij is. Het is strikt rationeel gezien dus niet verstandig aan 78 dit soort loterijen mee te doen, want de te verwachten opbrengst weegt niet op tegen het genomen risico. Smith geeft twee redenen waarom men toch geneigd is naar dit soort ongewisse beroepen als kansspelen mee te dingen:

Allereerst het verlangen naar de reputatie die superieure excellentie in deze beroepen met zich meebrengt, en ten tweede het natuurlijk vertrouwen dat iedere man in meer of mindere mate heeft in niet alleen zijn eigen kunnen, maar ook in zijn goed geluk. (ibid.) ${ }^{8}$ 
De meest recente en omvattende beschouwing over supersterinkomens vormt het boek The Winner-Take-All Society (1995) van de Amerikanen Frank en Cook. De strekking van het boek is dat de 'winner-take-all'-beloningsstructuur ook in andere sectoren van de economie doordringt, dat te veel mensen aan de 'rat race' naar supersterinkomens meedoen en dat een afroming van supersterinkomens via belastingen gewenst is. Hun voornaamste argument is dat elke deelnemer aan een superstercompetitie (bijvoorbeeld elke atleet of club die poogt kampioen te worden, elk bandje dat poogt een top-4o hit te scoren) alleen de eigen kosten en de kansen op het succes in beschouwing neemt, maar niet dat door hun deelname de kansen op succes van hun rivalen kleiner worden. Hoewel de inspanningen en investeringen van de ene atleet zijn kans op succes doen toenemen, neemt als negatief extern effect diezelfde kans voor de rivaliserende atleten af. Frank en Cook laten zien dat wanneer op voorhand niet duidelijk is wie de winnaar zal worden (de deelnemers moeten daarvoor onderling nog in het strijdperk treden), dat dan de maatschappelijke kosten van het te hoge aantal deelnemers de maatschappelijke baten te boven gaan. Niet alleen gaat voor elke deelnemer de kost voor de (onzekere) baat uit, maar ook zullen de gezamenlijke kosten (training en investering) van alle deelnemers tezamen de baten van hun activiteiten overtreffen en des te meer wanneer (I) de minder getalenteerden hun kansen op succes sterker overschatten, (2) er meer mensen gevoelig zijn voor de 'lure of fame', (3) talentverschillen moeilijker observeerbaar zijn en ten slotte (4) als alleen het relatieve en niet het absolute niveau van belang is.

De eerste twee componenten spreken voor zich: de maatschappij heeft niets aan een heel leger van dilettanten op allerlei gebied, die in hun jacht naar roem volharden en een andere carrière laten schieten. Ten aanzien van de derde component volstaat een tegenvoorbeeld: als voor iedereen op voorhand duidelijk is wie gaat winnen, en als alleen het winnen telt, dan heeft het geen zin zich nog verder te vermoeien. Een eigenaardig fenomeen dat dit aspect illustreert is bekend uit het antieke Athene waar sportlieden die zonder meer altijd wonnen, op den duur werden verbannen. Als men voor de wedstrijd aanvangt al weet wie er gaat winnen, dan kan de wedstrijd net zo goed niet plaatsvinden. Bij de laatste component ten slotte, het onderscheid tussen het belang van het relatieve dan wel het absolute niveau, gaat het erom dat het welvaartsverlies groter is als het louter gaat om een competitie waar alleen de onderlinge rangorde in het geding is, zoals bij sport het geval is. Bij competities waarin juist het absolute niveau dat de winnaars behalen van belang is, bijvoorbeeld de strijd tussen een aantal kandidaten om president-directeur van een multinational te worden, de competitie tussen studenten, de competitie tussen onderzoekslaboratoria naar nieuwe producten en technieken, is het welvaartsverlies van een te groot aantal deelnemers veel minder, als hiervan al sprake is. ${ }^{9}$ 


\section{Krijgen versus verdienen}

Met het overzicht van mogelijke factoren die aan supersterinkomens ten grondslag liggen, hebben we enig inzicht waarom supersterinkomens astronomische hoogten kunnen bereiken. De belangrijkste oorzaak is de imperfecte substitutie tussen kwaliteit in combinatie met goedkope reproductie. Het grootste deel van alle supersterinkomens (van popmusici, cabaretiers, schrijvers, talkshowpresentatoren, profsporters tot motivatietrainers) kan hiermee worden verklaard. Het voornaamste probleem, vanuit economisch oogpunt, is niet zozeer de hoogte van het supersterinkomen: hoe hoog deze inkomens ook zijn, op het totale inkomensvolume van een economie is het aandeel zeer gering. Veel schadelijker voor de maatschappij is het als te veel mensen te hardnekkig proberen de supersterstatus met het bijbehorende inkomen te bereiken. Als kan worden aangetoond dat supersterinkomens veel lager zouden moeten zijn dan nu het geval is en er ook maatregelen denkbaar zijn die dat bewerkstelligen, dan doet zich dit probleem niet meer voor, of in veel mindere mate.

Supersterren krijgen veel, maar verdienen (in letterlijke zin) ze het ook? Als voorlopig antwoord op deze vraag stellen we het volgende criterium voor: het inkomen dat iemand ontvangt, is ook daadwerkelijk verdiend als de waarde van de totale productie door zijn toedoen ook met dat bedrag toeneemt. Hierbij vraagt men zich dus af hoe groot het verlies in maatschappelijke welvaart zou zijn als de betreffende persoon niet bestaan zou hebben. Volgens de neoklassieke economische theorie is in een goed functionerende markt het loon doorgaans een weerspiegeling van deze marginale bijdrage aan de welvaart. Een simpel voorbeeld laat dit zien. Het inkomen van de boer die aardappelen teelt, is gelijk aan wat consumenten bereid zijn daarvoor te betalen, gegeven hun voorkeuren en het concurrerende aanbod van andere boeren. Bij een zeer groot aantal aanbieders heeft het aanbod van de ene boer geen invloed op de marktprijs, en de toegevoegde waarde kan derhalve worden gelijkgesteld aan de marktwaarde van zijn productie, wat weer gelijk is aan zijn inkomen. Om nu antwoord te geven op de vraag of supersterren ook verdienen wat ze nu krijgen, moeten we zien te achterhalen wat de meerwaarde is van supersterren aan de totale productie. Om de rol van de media of de reproductietechnologie te illustreren, maken we gebruik van het volgende, gestileerde, voorbeeld.

Stel dat er $n$ privaatdocenten zijn $(i=1,2, \ldots, n)$, die gerangschikt zijn naar niveau. De beste docent $n$ heeft niveau a en voor de overige docenten geldt dat hun niveau gelijk is aan $i^{*} a / n$. Tevens zijn er $n$ leerlingen, die ieder een docent contracteren en betalen naar rato van het niveau of de kwaliteit van het geboden onderricht. We krijgen dan de situatie zoals afgebeeld in het linker panel van de onderstaande figuur, waarbij de productie gelijk is aan de uit alle balkjes samengestelde driehoek. 
a

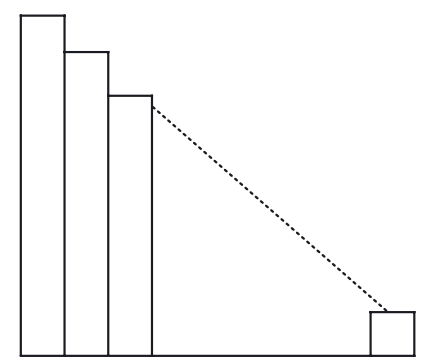

n a

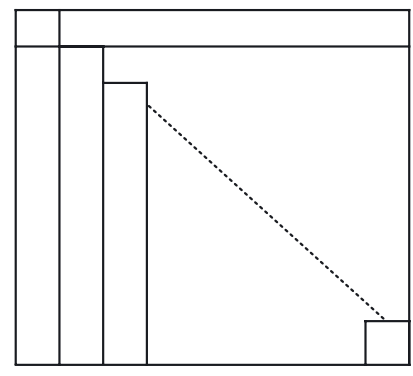

n

\section{Figuur 1}

De excellente docent laat nu een video-opname maken van zijn lessen en gaat deze verkopen. Omdat deze lessen van niveau a zijn, zijn alle leerlingen ook bereid er avoor te betalen. We krijgen dan de situatie zoals afgebeeld in het rechter panel, waarbij de productie is toegenomen met de driehoek rechtsboven. Als de prijs inderdaad op niveau ablijft, wat het geval is als consumenten geen genoegen willen nemen met een inferieure kwaliteit, dan is de beste docent in staat de gehele waarde van deze deelmarkt naar zich toe te trekken, waardoor hij het n-voudige verdient vergeleken met de situatie waarbij hij privé-onderwijs gaf.

Voor we het effect van een prijsdrukkende werking van concurrentie en schaalvergroting van de markt door het toetreden van nieuwe consumenten introduceren, is het op basis van deze figuren mogelijk de bijdrage van de beste docent te bepalen. Als alle nleerlingen de video tegen een prijs $a$ aanschaffen, dan is de productie gelijk aan $n^{*} a$. Maar stel dat de excellente docent ner niet was geweest, of niet op het idee was gekomen om zijn lessen te klonen middels video, en dat de één na beste leraar n-1 de video maakt. De kwaliteit van deze video is iets lager, want het niveau van deze docent is gelijk aan (n-1)a/n. Als alle nleerlingen deze video aanschaffen, dan is de productie gelijk aan $n(n-1) a / n=(n-1) a$. Door de afwezigheid van de excellente docent $n$ daalt de waarde van de productie dus van $n^{*} a$ naar $(n-1) a$. Het marginale product van de beste docent, dat is de bijdrage aan de productie door zijn toedoen, is dus gelijk aan het verschil in de waarde van de productie met en zonder de beste docent, en dit verschil is verrassenderwijs gelijk aan a.

De bijdrage van de beste docent is dus louter het kwaliteitsverschil tussen hem en zijn naaste concurrent, vermenigvuldigd met het aantal leerlingen dat van dit kwaliteitsverschil kan profiteren. Dit is in de rechterpanel van de figuur aangegeven met het horizontale balkje aan de bovenzijde. We weten echter ook dat a de beloning is die de beste docent zou ontvangen, wanneer hij enkel privé-onderwijs zou geven. De oppervlakte van het horizontale balkje in de rechterpanel, dat de bijdrage van de beste docent aan het geheel weergeeft, is precies gelijk aan de oppervlakte van het hoogste verticale balkje in de linkerpanel van de figuur. Met andere woorden, vol- 
gens deze analyse zou de superster niet meer mogen verdienen dan wat hij zou kunnen verdienen wanneer hij zijn diensten exclusief aan de hoogst biedende consument zou verkopen. Wil de supersterdocent zijn diensten middels media aan alle leerlingen aanbieden, dan zou de prijs van de video moeten dalen tot $a / n$, waardoor de nleerlingen tezamen aan de docent $n^{*} a / n$ $=a$ betalen om ervoor te zorgen dat de superster niet meer verdient dan zijn bijdrage aan de productie. Er is dan weliswaar nog wel een superster, maar er is geen sprake meer van een supersterinkomen. De introductie van een massamedium zou dan louter tot gevolg hebben, dat het inkomen van de superster verandert van een hoge prijs betaald door weinigen naar een lage prijs betaald door velen.

Of deze situatie zich inderdaad zal voordoen, hangt af van de prijsdrukkende werking van concurrentie tussen verschillende aanbieders, waardoor de prijs tot een zeer laag niveau kan dalen. Dit heeft tegelijkertijd een schaalvergroting van de markt tot gevolg, omdat nieuwe consumenten door de lagere prijs worden aangetrokken. Het is inderdaad zeer waarschijnlijk dat ook de andere docenten in staat zijn hun lessen op video te reproduceren en deze voor een lagere prijs dan a op de markt te brengen. Als de consumenten prijs en kwaliteit tegen elkaar afwegen, dan is het gevolg hiervan dat de prijs in rap tempo zal dalen. Dit veronderstelt echter wel dat consumenten prijs en kwaliteit tegen elkaar willen inruilen.

Bij de activiteiten waarin supersterren excelleren, is dit niet, of niet in voldoende mate, het geval. Waar de schoen wringt, is dat bij sport en andere amusement de prestatie van 'de beste' een bijzondere betekenis heeft en daardoor ook een bijzondere aantrekkingskracht. Een amateur kan weliswaar zijn roo meter-sprint op de markt aanbieden, maar hoe gering ook de prijs die hij er voor vraagt, er is geen vraag naar. Er is sprake van een extreem geval van imperfecte substitutie, zoals hierboven uiteengezet. Zij die hier vertrouwen op de prijsdrukkende werking van vrije concurrentie, zien over het hoofd dat er per definitie maar één de beste kan zijn, hoe velen dit er ook willen zijn. Zeker, steeds meer producten zoals boeken en cd's komen dankzij steeds goedkopere reproductietechnologie tegen steeds lagere prijzen op de markt. Maar supersterinkomens laten zich niet elimineren door toename van de concurrentie, omdat op superstermarkten toename van de concurrentie niet altijd een prijsdrukkend effect heeft. In sommige takken van de cultuurindustrie zijn er per definitie sterren met superinkomens, ongeacht wie het zijn. De plaats van dé beste is een 'absoluut schaars goed', en een toename van het aantal mededingers doet het feit dé beste te zijn alleen maar aan belang winnen. Vraag- en aanbodfactoren lijken hier een andere rol te spelen dan gewoon is binnen de gangbare economie. Als het zo is dat de prestatie van de superster (bijvoorbeeld de winnaar van de Ioo meter sprint, een optreden van een topartiest) gezien moet worden als een radicaal heterogeen product (wat we aangeven met de relevantie van de beste, het unieke) ten opzichte van de prestaties van anderen, dan wil dat zeggen dat ze onderling niet substitueerbaar zijn. Maar een bepaalde mate 
van substitueerbaarheid is noodzakelijk, opdat van het spel van vraag en aanbod een prijsdrukkende werking kan uitgaan.

Het is moeilijk aan te geven waarom men per se het beste wil (bijvoorbeeld een uitvoering van Pavarotti verkiest boven die van Lieuwe Visser). De paradox bij veel supersterprestaties is dat hoewel de verschillen slechts relatief én klein zijn, aan de prestatie van dé beste een absolute betekenis wordt toegekend. Men stoot hier op een karakteristiek van het supersterfenomeen dat nogal weerbarstig is, namelijk wat is de relevantie van dé beste? Vergelijk deze vraag met wat de relevantie is van het origineel van het kunstwerk ? $^{\text {IO }}$

Anders gesteld, de media zorgen ervoor dat iedereen kennis kan nemen van de prestaties van de besten en door de sterke imperfecte substitutie gaat de voorkeur uit naar het beste en nauwelijks naar wat zich daaronder afspeelt. Dit verklaart direct een andere karakteristiek van activiteiten waar supersterren zich manifesteren, namelijk dat men eigenlijk niet kan spreken van tekorten of overschotten. Er kan bijvoorbeeld wel een tekort aan loodgieters of aan technici zijn, maar men hoort nooit dat er een tekort is aan popzangers, atleten of nieuwslezers. Dit komt omdat, door de beschikbaarheid van een reproductietechnologie, in principe één of enkele 'geschikte' kandidaten reeds volstaan. De toe-eigening van deze lucratieve posities gebeurt doorgaans door onderlinge competitie. De sport is hiervan de beste illustratie. De winnaar heeft de facto tijdelijk het eigendomsrecht verkregen zich de beste te mogen noemen en dit eigendomsrecht is schaars en heeft een marktwaarde. De superster is in feite, zolang hij zijn positie als de beste kan handhaven, een monopolist. Het verschil met een gewoon monopolie is dat dan het alleenrecht wettelijk is toegewezen, zoals bij de PTT ten aanzien van het aanbieden van postdiensten of bij de Ns het spoorverkeer. De superster echter moet zijn monopolie (in het aanbieden van 'het beste') in competitieverband verwerven en weer afstaan, zodra hij zijn positie aan de top niet kan handhaven. In de volgende sectie wordt aan de hand van enkele actuele voorbeelden uit de sportwereld geïllustreerd dat supersterren, juist vanwege hun unieke positie als monopolist, gauw in conflict kunnen komen met andere belanghebbende partijen, te weten de sportbonden en de overige deelnemers.

4. De investituurstrijd in de schaakwereld en andere belangenconflicten in de sport

In zijn algemeenheid kunnen we stellen dat een groot deel van de conflicten waardoor de sportwereld zo nu en dan wordt opgeschrikt, te maken heeft met conflicten tussen kampioenen en sportbonden, bijvoorbeeld die tussen Rintje Ritsma en de KNSB, Ajax, Feyenoord en PSV contra de KNVB, Kasparov contra de FIDE, (dit conflict wordt meer uitvoerig uiteengezet in Borghans en Groot 1997). In al deze conflicten gaat het om de vraag welk 
deel van de totale commerciële waarde van de activiteit waar het om gaat, aan de kampioenen toevalt en welk deel aan de overige deelnemers aan de competitie via een herverdelende bond. Hierbij dient te worden opgemerkt dat de commerciële waarde van een sport doorgaans tamelijk onafhankelijk is van deze of gene club of atleet, bijvoorbeeld de totale marktwaarde van voetbal, tennis, basketbal toont een door de jaren heen gestage opgaande lijn, terwijl de beste spelers in deze sporten komen en gaan. Het is namelijk niet zo dat door het vertrek van deze of gene sterspeler de totale omzet in deze branche daalt.

Het belangenconflict tussen superster en sportbond heeft zich midden jaren negentig tamelijk dramatisch voorgedaan in de schaakwereld en is nog steeds niet beslecht. Kasparov, feitelijk de wereldkampioen en Short, destijds de winnaar van de FIDE-kandidatenmatches, hadden een eigen organisatie opgericht bedoeld om de hoge afdrachten aan de FIDE te omzeilen. De FIDE claimde $25 \%$ van de opbrengst van toptoernooien, haar voornaamste bron van inkomsten, die onder andere wordt gebruikt om wereldwijd op verschillende niveaus toernooien en competities op lagere niveaus te organiseren. De PCA (Professional Chess Association) van Kasparov en Short was enkel bedoeld voor de professionals, zoals ook de professionele tennisspelers een eigen organisatie hebben. De reactie van de FIDE op het onttrekken van de meest prestigieuze wedstrijd aan haar jurisdictie was dat de eerder uitgeschakelde halve finalisten van de kandidatenmatch (Karpov en Timman) alsnog werden uitgenodigd te spelen om de FIDE-wereldtitel. Het is niet verwonderlijk dat het de FIDE grote moeite heeft gekost om sponsors voor deze wedstrijd te vinden, want iedereen weet dat hier een fake-kampioenschap werd geënsceneerd terwijl elders de echte kampioenen aan het werk waren. Het is echter evident dat de match tussen Timman en Karpov niet onaantrekkelijk was vanwege het slechte spel van beide spelers. Als Kasparov in zijn jeugd besloten had om dammer te worden en Short in de kandidatenmatch van Timman had verloren, of als beiden eenvoudigweg niet bestaan hadden, dan had deze wedstrijd in het middelpunt van de belangstelling gestaan. Dit laat overduidelijk zien dat de kampioensrol belangstelling naar zich toetrekt die in principe voor de betreffende sport als zodanig bestaat. Zowel de bond als de topspelers of -clubs kunnen dus bogen op een machtspositie, waartussen de kleinere 84 spelers moeten manoeuvreren (meedoen met de PCA of de FIDE, in de kernploeg blijven of zich aansluiten bij een commerciële schaatsploeg, vasthouden aan de oude eredivisie of meedoen met een superliga).

Tot op de dag van vandaag is dit schisma, waardoor er zowel een FIDEals een PCA-wereldkampioen is, nog niet beslecht. Soortgelijke schisma's zijn nog steeds aanwezig in de bokswereld, waar iedere organisatie haar eigen kampioenen heeft. Wezenlijk draait het in dit soort conflicten altijd om de vraag welk deel van de commerciële waarde van een sport opgeëist kan worden door de winnaars en welk deel toekomt aan de organiserende bond, die het vervolgens nog moet verdelen onder zijn leden. Let wel, de 
commerciële waarde van een sport komt alleen tot stand door de competities. Zelfs de kampioenen zijn afhankelijk van (de aantrekkelijkheid van) deze competities. Anderzijds zal elke competitie een winnaar opleveren, met de daarbijbehorende machtspositie ten opzichte van de bond. Het is daarom in het belang van de bond, en waarschijnlijk ook in het belang van de aantrekkelijkheid van de competitie, dat de verschillen aan de top zo klein mogelijk zijn, met als gevolg een spannende competitie en een snelle doorstroom van kampioenen.

Dit laatste is juist wat wordt nagestreefd door de sportbonden in de Amerikaanse competities, zoals de NBA-basketbalcompetitie. De kern van de regulering van de NBA-competitie (zie Eeden I993: 45 e.v.) is, dat sinds I983 alle aangesloten clubs een gelijk salarisbudget (de befaamde salary cap) ter beschikking staat en dat clubs die in het voorgaande jaar de play offs niet hebben gehaald als eersten de beste talenten uit de college-competition kunnen aantrekken (de zogenaamde lottery day). ${ }^{\mathrm{II}}$ Door de salary cap is een club gedwongen te kiezen het team samen te stellen uit één of enkele toppers met daarnaast wat zwakkere spelers of een team te formeren met louter spelers uit de middencategorie. Door de tweede maatregel wordt beoogd de competitie jaar in jaar uit in balans te houden, door het minder presterende clubs gemakkelijker te maken zich te versterken dan beter presterende clubs. ${ }^{\text {I2 }}$ Voorts moet elke club een entreebewijs kopen (in het seizoen I992-93 32,5 miljoen dollar) om überhaupt aan de competitie te mogen meedoen en worden de inkomsten van de bond, zoals uit de landelijke tv-contracten, gelijkelijk over de clubs verdeeld. Dit geeft aan dat er allerlei maatregelen denkbaar zijn die een gelijkere verdeling van inkomsten over alle deelnemers aan een competitie bevorderen.

Een laatste voorbeeld is de recente staking in het Italiaanse profvoetbal wegens een conflict over de televisierechten, waardoor de competitie 20022003 van de Serie A twee weken later dan gepland was, begonnen. De twee pay-per-view televisiezenders Stream en Telepiu boden voor de wedstrijden van de kleine clubs in de Serie A slechts $€$ 4,5 miljoen tegenover $€$ 6o miljoen voor de wedstrijden van de grote clubs zoals Inter Milan of Juventus. De kleine clubs hielden vast aan een vraagprijs van $€$ io miljoen. In reactie op de weigering van de kleine clubs de competitie te beginnen, zijn de grote clubs van de Serie A overstag gegaan en hebben eenmalig een bedrag toegezegd aan de kleine clubs. ${ }^{\text {I3 }}$

De voorbeelden hierboven laten zien dat er bij een coördinerende sportbond allerlei maatregelen denkbaar zijn om de commerciële waarde van sporten op een andere manier te laten neerslaan dan louter bij de sterspelers of de topteams. We willen deze sectie besluiten met twee voorbeelden, de een reëel en de ander nog ideëel, van een radicaal voorstel waarbij het inkomen van supersterren terugkeert naar het niveau overeenkomstig de bijdrage aan de welvaart zoals wij in paragraaf 3 hebben uiteengezet. Ten eerste, de laatste ontwikkelingen van dezelfde technologie die ervoor heeft 
gezorgd dat popsterren hun intrede konden doen, zorgen er nu voor dat hun voornaamste bron van inkomsten dreigt weg te vallen, namelijk de royalty's op cd's, boeken, films en de uitzendrechten. De Amerikaanse econoom Krueger (2002) heeft recentelijk laten zien dat sinds Napstar en MP3 opkwamen op het internet, de prijzen van popconcerten gigantisch zijn gestegen. De meest voor de hand liggende verklaring is dat concerten en cdverkoop complementair zijn. Waar vroeger artiesten relatief goedkoop concerten gaven om daarmee hun cd te promoten, lukt het hen tegenwoordig steeds minder om met cd-verkoop veel geld binnen te halen en moeten ze noodgedwongen hun via 'illegale' MP3-bestanden verworven populariteit, te gelde maken middels live-concerten. Het lijkt er haast op dat de voortschrijding van de techniek ervoor heeft gezorgd dat de kosteloze verspreiding van muziek ook gratis is en dat de artiest wordt gedwongen zijn geld weer te verdienen met activiteiten waarbij voor een vergroting van de omzet ook een grotere inspanning is vereist. Hoewel de artiesten hierbij terugkeren in de normale wereld, is het niet vanzelfsprekend dat het inkomen dat zij hiermee verdienen de juiste afspiegeling van hun maatschappelijke bijdrage is. De zoektocht naar nieuwe eigendomsprincipes is dus nog niet afgelopen.

Al met al lijkt het er dus op dat we door de opkomst van digitale technieken en internet steeds vaker terechtkomen in een situatie waar alleen nog maar de beste of meest getalenteerde het werk hoeft te leveren om iedereen te voorzien van producten met de hoogste kwaliteit. Hoewel dit uiteraard tot een enorme vergroting van de welvaart kan leiden, blijken de oude eigendoms- en mededingingsprincipes de overgang naar deze nieuwe omstandigheden tegen te werken. Het idee dat het inkomen de marginale bijdrage aan de welvaart moet weerspiegelen, blijft niettemin als baken overeind. In dit licht zou men ook voor sport een coderingsverbod, idealiter aangevuld met een reclameverbod, kunnen overwegen bij het uitzenden van reportages van sportevenementen die nu nog commercieel worden uitgebaat middels een massamedium (zie voor een verdediging van dit voorstel vanuit welvaarttheoretisch oogpunt Van der Burg 1996: 710). Het punt waar het hier om draait, is dat het toekennen van eigendomsrechten aan afzonderlijke clubs (zoals het Ministerie van Economische Zaken voorstaat in de kwestie rond het verbod op collectieve uitbating van uitzendrechten),

86 betekent dat de topclubs hun machtspositie in het aanbieden van het beste als monopolist zullen uitbaten.

Nog mooier zou het zijn als bij de beloning van sporters expliciet afgewogen zou worden welke bijdrage deze sporter aan de sport als zodanig levert. In de Verenigde Staten is het, zoals al is opgemerkt, gebruikelijk om de competitie als geheel als één product te zien. De bond kan daardoor binnen de competitie regels maken om de balans in de competitie te bevorderen. De mededingingsautoriteit gaat ervan uit dat de economische concurrentie tussen verschillende competities plaatsvindt. Hoewel het systeem in de vs beter functioneert dan het Europese systeem, waar concurrentie 
tussen clubs wordt benadrukt, zijn er zowel praktische als theoretische bezwaren om sportbonden als concurrenten te beschouwen. Veel supporters hebben immers een sterke band met 'hun' sport en 'hun' club en zullen dus niet van voetbal op korfbal overstappen, omdat de entreekaartjes goedkoper zijn. Meer fundamenteel kan men stellen dat de keuze voor voetbal of schaatsen als favoriete sport niet gebaseerd is op een afweging van kosten en amusementswaarde, maar dat de betekenis van deze sporten cultureel bepaald is. Doordat kinderen van jongs af aan opgroeien in een land waar voetbal de sport is, en 's winters menigeen voor de buis gekluisterd zit om de schaatskampioenschappen te bekijken, hebben deze sporten betekenis voor hen gekregen. Een sport als voetbal kan daarom het beste gezien worden als een cultureel erfgoed en het lijkt niet logisch om een bond met winstoogmerk en aandeelhouders eigenaar van zo'n maatschappelijk goed te maken. Een dergelijke bond zal uiteraard de rol van de topspelers zien, maar deze ook in het perspectief van de sport in zijn geheel kunnen plaatsen. Profsport en supersterren zullen blijven, alleen de torenhoge inkomens zullen tot het verleden behoren.

\section{Conclusie}

Als de producenten binnen een afzetmarkt de beschikking hebben over een technologie waarmee tegen steeds lagere reproductiekosten het product in principe oneindig kan worden gekloond, dan bestaat de mogelijkheid dat enkelen (de besten) met uitsluiting van alle mogelijke concurrenten de gehele toegevoegde waarde van deze markt naar zich toe trekken. Supersterren kunnen daarom goedbeschouwd worden gezien als monopolisten van een bijzondere soort, namelijk in de zin dat zij eerst moeten bewijzen dat ze de beste zijn en vervolgens, voor zolang hun superioriteit duurt, de enigen zijn die 'het beste' kunnen aanbieden. Typerend voor dit soort winnaarslonen is dat alleen het winnen telt: anderen ontvangen (nagenoeg) niets. Simpel gesteld komt het hier op neer dat bij kosteloze reproductie het kleine onderscheidmakende verschil (het winnen met een spreekwoordelijk 'banddikte' verschil) van doorslaggevende betekenis wordt. Binnen hun deelmarkt zijn zij 'eersten onder gelijken' en toch valt hen als beloning het leeuwendeel van het geheel toe.

Verschillende verklaringen voor deze winnaarslonen zijn de revue gepasseerd: imperfecte substitutie in combinatie met kosteloze of goedkope reproductie, de tijdkosten van consumptie, de formatie van consumptiekapitaal en, niet onbelangrijk, geluk. Vervolgens is geprobeerd aanschouwelijk te maken dat wanneer in het extreme geval de superster in staat is de hele toegevoegde waarde van een deelmarkt naar zich toe te trekken, zij veel meer ontvangt dan wat haar toekomt op grond van de geleverde bijdrage aan de welvaart. Wat dan in feite gebeurt is dat supersterren de commerciële waarde van een cultureel erfgoed als voetbal of muziek te gelde ma- 
ken. Dit is geen natuurverschijnsel, maar het logisch product van hoe superstermarkten momenteel werken. Voorts hebben we laten zien dat een machtige sportbond die de competitie reguleert, steun geeft aan jeugdteams en amateurs en ervoor zorgt dat voetbal voor iedereen toegankelijk blijft op een publieke zender, gezien kan worden als vertegenwoordiger van het publieke belang. Een andere mogelijkheid waarop is gewezen, is het opleggen van een coderingsverbod bij sportuitzendingen, waardoor het belang van niet-media gebonden inkomensbronnen als stadionbezoek zal toenemen. Vanuit ditzelfde perspectief moet de huidige tendens van massaal kopiëren van muziek- en beeldmateriaal op internet wellicht niet worden gezien als een bedreiging maar eerder worden toegejuicht.

\section{Noten}

1 Supersterren worden wel eens gezien als de 'heiligen' van deze tijd.

2 Zo constateerde de jonge Marx (1842: 109), die als journalist werkzaam was bij de Rheinische Zeitung, dat door de opkomst van de mijnbouw en industrie steeds vaker rechtszaken werden gevoerd over zaken die voorheen via gewoonterecht duidelijk geregeld waren. Zo werd de gewoonte van boeren om in het bos hout te sprokkelen, plotseling gezien als houtdiefstal.

3 There are some very agreeable and beautiful talents of which the possesion commands a certain sort of admiration; but of which the exercise for the sake of gain is considered, whether from reason or prejudice, as a sort of public pense, therefore, of those who exercise them in this manner must be sufficient, not only to pay for the time, labour, and expense of acquiring the talents, but for the discredit which attends the employment of them as the means of subsistence. The exorbitant rewards of players, opera-singers, opera-dancers, etc. are founded upon those

4 It seems absurd at first sight that we should despise their persons and yet reward their talents with the most profuse liberality. While we do the one, however, we must of necessity do the other. Should the public opinion or prejudice ever alter with regard to such occupations, their pecuniary recompense would quickly diminish. More people would apply to them, and the competition would quickly reduce the price of labour. Such talents, though far from being common, are by no means so rare as is imagined. Many people possess them in great perfection, who disdain to make use of them; and many more are capable of acquiring them if anything could be made honourably by them.

5 To reemphasize, the star need not possess greater talent. Stardom is a market device to economize on learning costs in activities where 'the more you know the more you enjoy'. Thus stardom may be independent of the existence of a hierarchy of talent. 
6 First, bills of all colors could serve as money and likewise all artists could be stars. Second, efficiency calls for only one money and likewise efficiency calls for very few artists with public recognition (...) If there were a slight majority of consumers that picked $X$ as their choice, $X$ would snowball into the star because after each period this majority would increase.

7 Put your son apprentice to a shoemaker, there is little doubt of his learning to make a pair of shoes; but send him to study the law, it is at least twenty to one if ever he makes such proficiency as will enable him to live by the business. In a perfectly fair lottery, those who draw the prizes ought to gain all that should have been gained by the unsuccessful twenty. The counsellor of law who, perhaps, at near forty years of age, begins to make something by his profession, ought to receive the retribution, not only of his own so tedious and expensive education, but that of mere than twenty others who are never likely to make anything by it.

8 First, the desire of reputation which attends upon superior excellence in any of them; and, secondly, the natural confidence which every man has more or less, not only in his own abilities, but in his own good fortune.

9 Om uitvindingen en ontdekkingen te stimuleren, is het dus zeer goed verdedigbaar om tijdelijk patenten toe te kennen.

10 Vergelijk Walter Benjamin (1970). Hoewel reproductie en mimesis van alle tijden is, al was het maar als oefening in vakbekwaamheid, zet volgens Benjamin de technische reproductie zich met steeds grotere intensiteit door. In de oudheid was reproductie beperkt tot munten, later komen houtsneden en kopergravures, maar al het andere was principieel éénmalig. Boekdrukkunst, fotografie, film, geluidsopname en de computer brengen hierin een fundamentele verschuiving teweeg. Benjamin vraagt zich af 'of door de uitvinding van de fotografie niet het totale karakter van de kunst veranderd was'. Het belang van echtheid, de relevantie van het origineel, is volgens Benjamin het effect van de mogelijkheid tot reproductie.

11 Vergelijk dit met de praktijk in Nederland. De meest talentvolle jonge speler van dit moment, Arjen Roben, gaat van Groningen naar de topclub PSV, waardoor de eerste nog steviger onderaan de ranglijst bungelt.

12 Het feit dat de Chicago Bulls het laatste decennium vaak in de finale heeft gestaan, laat zien dat deze opzet niet helemaal is geslaagd. Dit komt omdat het clubsalaris van een speler nog maar een fractie bedraagt van het totale inkomen inclusief sponsorcontracten. Voor sterspelers is het dus nog steeds interessant om samen in een kampioensteam te zitten, omdat dit hun marketingwaarde sterk verhoogt.

13 Voor nadere bijzonderheden over dit conflict, zie The Guardian, August 20 en September 10, 2002. 
Lex Borghans en Loek Groot Supersterren en superinkomens

\section{Geraadpleegde literatuur}

Adler, M. (1985) Stardom and Talent. American Economic Review, 75: 208212.

Benjamin, W. (1970) Het kunstwerk in het tijdperk van zijn techniese reproduceerbaarheid, sun, Nijmegen.

Macdonald, G. (1988) The Economics of Rising Stars. American Economic Review, 78 (1) 155-166.

Borghans, L. en L.F.M. Groot (1997) Het belangenconflict tussen sportbonden en kampioenen. Economisch Statistische Berichten, 82 (4098) 231-232.

Burg, T. van der (1996) Het voetbalmonopolie. Economisch Statistische Berichten, 81 (4069) 710-2.

Eeden, E. van (1993) In de ban van de ring. Intermediair, 29 (5) 45-51.

Frank, R.H. en P.J. Cook, The-WinnerTake-All Society, New York: Free Press.
Krueger, A. (2002) The Economics of Real Superstars: The Market for Rock Concerts in the Material World, paper gepresenteerd op SOLE 2002 conference (verschijnt in the Journal of Labor Economics).

Marx, K. (1842/1983) Verhandlungen des 6. rheinischen Landtags; Dritter Artikel: Debatten über das Holzdiebstahlsgesetz, band $1 \mathrm{MEv}$, Berlin: Dietz Verlag (oorspronkelijk verschenen in Rheinische Zeitung nr. 298, 25 oktober 1842).

Rosen, S. (1981) The Economics of Superstars. American Economic Review, 71: 845-858.

Rosen, S. (1983) The Economics of Superstars: Reply. American Economic Review, 73: 460-462.

Smith, A. (1776/1982) An Inquiry into the Nature and Causes of the Wealth of Nations, Middlesex: Penguin. 